\title{
Propionibacterium Acnes Infections After Cranial Neurosurgery
}

\author{
Michael E. Kelly, Daryl R. Fourney, Raphael Guzman, Venkatraman Sadanand \\ Robert W. Griebel, Stephen E. Sanche
}

\begin{abstract}
Background: Propionibacterium acnes (P. acnes) is a relatively avirulent organism that is part of the normal skin flora. Most patient isolates are considered contaminants but, in a small subset of patients, particularly in the post-neurosurgery setting, the organism can cause significant infections. We reviewed our experience with the occurrence and management of $P$. acnes infections after cranial neurosurgical procedures over a five-year period. Methods: Patients with positive cultures for P. acnes between 1996 and 2001 were identified by review of the Saskatoon Health Region microbiology laboratory database. Of the 141 positive cultures, a review of hospital records identified six patients with $P$. acnes infections after neurosurgical procedures. A review of the literature related to P. acnes associated CNS infections was conducted. Results: All patients had undergone a craniotomy or burrhole placement, and one patient had received prior radiotherapy. There were no $P$. acnes-related ventriculoperitoneal shunt infections. All patients presented with scalp swelling and three had purulent discharge. Symptoms occurred more than two months after the initial surgery in five of six patients, while one patient developed symptoms three years post-operatively. Management for all patients included removal of the craniotomy flap and treatment with parenteral antibiotics, followed in most cases by oral antibiotics. A good response without relapse of infection was seen in five patients; one patient had recurrent infection after cranioplasty. Conclusions: P. acnes is a rare but important cause of infection after craniotomy. Wound debridement, removal of the bone flap and adequate antibiotic coverage result in cure in the majority of patients.
\end{abstract}

RÉSUMÉ: Infection à Corynebacterium acnes après une neurochirurgie crânienne. Contexte : Le Corynebacterium acnes est un organisme relativement avirulent qui fait partie de la flore cutanée normale. On considère que la plupart des isolats de patients sont des contaminants. Cependant chez un petit sous-groupe de patients, particulièrement après une neurochirurgie, ce microorganisme peut causer des infections importantes. Nous revoyons notre expérience sur une période de 5 ans de l'infection à C. acnes et de son traitement après une neurochirurgie crânienne. Méthodes : Nous avons identifié les patients dont la culture démontrait la présence de C. acnes entre 1996 et 2001 au moyen d'une revue de la base de données du laboratoire de microbiologie de la région sanitaire de Saskatoon. 141 cultures positives ont été identifiées, dont six provenaient de patients ayant subi une neurochirurgie. Nous avons effectué une revue de la littérature sur les infections à C. acnes du SNC. Résultats : Tous les patients avaient subi une craniotomie ou un trou de trépan et un patient avait reçu de la radiothérapie avant l'intervention. Il n'y avait pas de cas relié à une dérivation ventriculopéritonéale. Les patients ont tous présenté un gonflement du cuir chevelu et trois présentaient un écoulement purulent. Les symptômes sont survenus plus de 2 mois après la chirurgie chez cinq des six patients alors que chez l'autre ils sont survenus trois ans plus tard. Tous les patients ont reçu le même traitement, soit l'ablation du volet osseux avec antibiothérapie par voie parentérale suivie, dans la plupart des cas, d'antibiothérapie par voie orale. Cinq patients ont bien répondu au traitement, sans récidive. Un patient a eu une récidive après une cranioplastie. Conclusions : Le C. acnes est une cause d'infection rare mais importante après la craniotomie. Le débridement et l'ablation du volet osseux ainsi qu'une antibiothérapie adéquate assurent la guérison chez la majorité des patients.

Can. J. Neurol. Sci. 2006; 33: 292-295

Propionibacterium acnes (P. acnes) is an anaerobic grampositive bacillus found as a normal component of the bacterial flora of the skin, hair follicles and sebaceous glands. Although the majority of patient isolates are thought to be contaminants, Propionibacterium acnes does cause significant disease in a small subset of patients after neurosurgical procedures. ${ }^{1}$ Ventriculoperitoneal shunt infections are the most commonly reported type of $P$. acnes infection in the neurosurgical literature. ${ }^{2,3}$ However, several reports describe $P$. acnes infections after craniotomy ${ }^{4-8}$ and it has been suggested that central nervous system infections caused by $P$. acnes are more important than previously recognized. We report on our single center experience and present one of the largest series of postcraniotomy $P$. acnes infections; we also reviewed the relevant literature.

From the Department of Neurosurgery (MEK, RG), Stanford University Medical Center, Stanford, California; Division of Neurosurgery (DRF, VS, RWG), and Division of Infectious Diseases, Department of Medicine (SES), Royal University Hospital and University of Saskatchewan, Saskatoon, SK, Canada.

ReCEIVED JANUARY 3, 2006. ACCEPTED IN FINAL FORM APRIL 22, 2006. Reprint requests to: Michael Kelly, Department of Neurosurgery, Stanford University Medical Center, Stanford, California, USA, 94305-5327. 


\section{Methods}

A search of the Saskatoon Health Region Laboratory Information System identified 141 cultures positive for $P$. acnes at our institution over five years (June 1, 1996 to May 31, 2001). Review of the hospital records revealed 13 patients with positive $P$. acnes cultures after neurosurgical interventions. Patient data including age and gender, procedure performed, type of surgical skin preparation, laboratory data including culture results, infection-related symptoms, medical and surgical management, and clinical outcome were collected. Positive cultures were classified as contaminants if the patient had no clinical symptoms. Based on a medical chart review, six patients were determined to have had definite clinical $P$. acnes infections.

For the literature review, an English-language Medline search was conducted using the key words "propionibacterium", "acnes" and "neurosurgery". Additional references were identified from citations in the papers found in the search.

\section{RESULTS}

Patient and treatment data are summarized in Table 1. There were four male and two female patients with a mean age of 48.5 (range, 11-67) years. Surgical procedures preceding the infection included placement of burrholes for a chronic subdural hematoma in one case, and craniotomy in the other five patients. Two patients had craniotomies for management of ruptured intracranial aneurysms, one for an acute subdural hematoma, one for decompression of bilateral optic nerve meningiomas, and one for a brain metastasis. The latter patient had received whole brain radiation therapy (50 Gray) one month prior to the onset of symptoms.

An iodine based skin preparation had been used prior to all of the surgical procedures, and all patients had received prophylactic intravenous cefazolin intra-operatively and for the first 24 hours post-operatively.

The mean time to symptom onset in five patients was 8.4 (range 4-14) weeks postoperatively. Patient 6 who had been treated for optic nerve meningiomas was unique in that symptoms did not develop until 192 weeks after surgery.

All six patients underwent repeat surgery after they presented with symptoms suggestive of infection. The five patients with prior craniotomies had removal of the infected bone flap. The patient with initial burrhole placement (Case 3) underwent craniotomy at the time of repeat surgery to facilitate drainage of a subdural empyema. Cultures were obtained from the surgical site in all patients. In five cases, $P$. acnes was isolated from both fluid and solid culture media incubated under anaerobic conditions. In one patient, (Case 4) P. acnes was isolated only

Table 1: Clinical characteristics of six patients with $P$. acnes infections after cranial neurosurgical procedures

\begin{tabular}{|c|c|c|c|c|c|c|c|c|}
\hline $\begin{array}{l}\text { Case } \\
\text { no. }\end{array}$ & Age & Sex & Underlying Disease & $\begin{array}{l}\text { Initial } \\
\text { Surgical } \\
\text { Procedure }\end{array}$ & $\begin{array}{l}\text { Onset of } \\
\text { Symptoms } \\
\text { (weeks) }\end{array}$ & Antibiotic treatment & Surgical treatment & Reconstruction \\
\hline 1 & 62 & $\bar{F}$ & $\begin{array}{l}\text { Brain metastasis (lung } \\
\text { cancer) }\end{array}$ & Craniotomy & 8 & Vancomycin IV x 6 wks & Removal bone flap & $\begin{array}{l}\text { Cranioplasty at } 6 \\
\text { mos }\end{array}$ \\
\hline 2 & 45 & $\mathrm{~F}$ & Aneurysm & Craniotomy & 8 & $\begin{array}{l}\text { Ciprofloxacin po, metronidazole po, } \\
\text { vancomycin IV x } 6 \text { wks }\end{array}$ & Removal bone flap & $\begin{array}{l}\text { Cranioplasty at } 6 \\
\text { mos }\end{array}$ \\
\hline 3 & 55 & $\mathrm{M}$ & $\begin{array}{l}\text { Chronic subdural } \\
\text { hematoma }\end{array}$ & Burrholes & 8 & Cefazolin IV x 5 wks & $\begin{array}{l}\text { Craniectomy and } \\
\text { evacuation of subdural } \\
\text { empyema }\end{array}$ & $\begin{array}{l}\text { Cranioplasty at } 5 \\
\text { mos }\end{array}$ \\
\hline 4 & 51 & M & $\begin{array}{l}\text { Acute subdural } \\
\text { hematoma }\end{array}$ & Craniotomy & 4 & $\begin{array}{l}\text { Cefazolin IV X } 1 \mathrm{wk} \text {, then cephalexin } \\
\text { po } x 8 \mathrm{wks}\end{array}$ & Removal bone flap & $\begin{array}{l}\text { Cranioplasty at } 7 \\
\text { mos }\end{array}$ \\
\hline 5 & 67 & $\mathrm{M}$ & Aneurysm & Craniotomy & 14 & Clindamycin po x $3 \mathrm{wks}$ & Removal bone flap & $\begin{array}{l}\text { Cranioplasty at } 6 \\
\text { mos }\end{array}$ \\
\hline 6 & 11 & M & $\begin{array}{l}\text { Bilateral optic nerve } \\
\text { meningioma }\end{array}$ & $\begin{array}{l}\text { Craniotomy } \\
\text { (bilateral) }\end{array}$ & 192 & $\begin{array}{l}\text { 1) Piperacillin/tazobactam IV } \times 2 \\
\text { weeks then ceftriaxone IV } \times 8 \text { wks } \\
\text { 2) Ceftriaxone IV } \times 4 \text { weeks } \\
\text { 3)Piperacillin/tazobactam IV x } 8 \text { wks }\end{array}$ & $\begin{array}{l}\text { Removal bone flap, } 2 \\
\text { failed cranioplasties }\end{array}$ & $\begin{array}{l}3 \text { recurrent } \\
\text { infections, no } \\
\text { final cranioplasty }\end{array}$ \\
\hline
\end{tabular}


from fluid media; this patient was included in the series because he clearly had infection-related symptoms.

Following surgical drainage and adjunctive antibiotic therapy, five of the six patients had complete resolution of infection and underwent cranioplasty six months later without further incident. A number of different antibiotic regimens were used for these patients (Table 1). Two patients, one of whom also received concurrent oral ciprofloxacin and metronidazole, were treated with intravenous vancomycin for six weeks. Two patients received intravenous cefazolin, although one patient was stepped down to oral cephalexin after one week. One patient was treated with a three week course of oral clindamycin. The patient with relapsing infection (Case 6) had two attempts at cranioplasty; $P$. acnes infection recurred each time, necessitating removal of the cranioplasty material and multiple courses of parenteral antibiotics: piperacillin-tazobactam (two weeks) followed by ceftriaxone (eight weeks) for the first episode, a four week course of ceftriaxone for the second, and a final eight week course of piperacillin-tazobactam.

\section{Discussion}

This study accounts for 6 of 25 patients (in 9 studies including our own) published in the literature. ${ }^{4-6,8-12}$ To our knowledge, it is the largest published series on this topic. Our study summarizes the early management plans and outlines our recommendations based on these findings. This study is also unique because there were no cases of ventriculoperitoneal shunt infections.

Propionibacterium species are non-spore forming anaerobic gram positive bacilli. Propionibacterium acnes, the species most commonly isolated from human specimens, is part of the normal bacterial flora of the skin, conjunctivae and oropharynx. In the majority of cases, $P$. acnes strains isolated from humans represent clinically insignificant contaminants. In a comprehensive review of Propionibacterium species recovered over 10 years at the National Naval Medical Center, 94 of 816 (12\%) isolates were determined to have caused infection based on review of medical records. Eleven of these patients had central nervous system infections. ${ }^{1}$ A similar review of Propionibacterium species isolates from pediatric patients at seven US hospitals over a 15 -year period showed similar results: 50 of $386(13 \%)$ were considered to be causing infection, including five involving the central nervous system. ${ }^{13}$ In both reviews, approximately $70 \%$ of the patients had predisposing conditions such as prosthetic material at the site of infection or preceding surgery.

Propionibacterium acnes can be recovered in highest concentrations from areas with high densities of hair follicles such as the scalp. ${ }^{14}$ Kamme et $\mathrm{al}^{7}$ conducted a study in which skin at neurosurgical operative sites was cultured just before incision in patients who had received pre-operative skin cleansing. They demonstrated that $P$. acnes was isolated more frequently and in larger quantities than other members of the normal skin flora. Subsequently, van Ek et al ${ }^{15,16}$ analyzed the effect of cloxacillin prophylaxis on the bacterial flora of craniotomy wounds in a randomized, placebo-controlled trial. Propionibacterium acnes and Staphylococcus epidermidis were the two most frequently isolated organisms from wound cultures taken at the time of initial surgery. Analysis of culture results showed a statistically significant reduction in $S$. epidermidis infections with cloxacillin prophylaxis, while the initial percentage of cultures positive for $P$. acnes did not differ between the placebo and cloxacillin -treated groups. The two studies described above illustrate the ability of $P$. acnes to survive surgical wound preparation and antibiotic prophylaxis, providing a potential mechanism for entry into wounds during neurosurgical procedures.

Successful management of $P$. acnes infections of the central nervous system requires surgical drainage followed by appropriate antibiotic treatment. Antibiotic choice should be based both on in vitro activity and central nervous system (CNS) penetration. Penicillin $\mathrm{G}$ and cephalosporins such as cefotaxime and ceftriaxone would be preferred choices based on these criteria. Clindamycin is an active drug in vitro but it has poor CNS penetration, and metronidazole penetrates the CNS well but is less active against $P$. acnes than it is against most other anaerobic bacteria. Interestingly, several successfully treated patients in our series and in the previously published reports that we reviewed received antibiotic regimens that might not be predicted to be successful based on the spectrum and/or pharmacokinetics of the drugs that they received. This suggests that thorough surgical evacuation of infected material may be more important to the outcome than the post-operative antibiotic regimen. Based on our experience and the literature review, it is

Table 2: Summary of $P$. acnes infections after craniotomy reported in the literature

\begin{tabular}{|c|c|c|}
\hline Author & Findings & Management \\
\hline Barazi et al. ${ }^{9}$ & $\begin{array}{l}1 \text { case of brain abscess } 18 \text { months } \\
\text { after craniotomy for tumor excision }\end{array}$ & $\begin{array}{l}\text { Removal of abscess cavity } \\
\text { Cefotaxime IV x } 2 \text { weeks, then } \\
\text { clindamycin po x } 10 \text { weeks }\end{array}$ \\
\hline $\begin{array}{l}\text { Bruce and } \\
\text { Bruce. }{ }^{10}\end{array}$ & $\begin{array}{l}4 \text { cases of } P \text {. acnes infection } \\
\text { (including } 1 \text { coagulase negative } \\
\text { Staphylococcus co-infection) without } \\
\text { intradural involvement after } \\
\text { craniotomy for tumors }\end{array}$ & 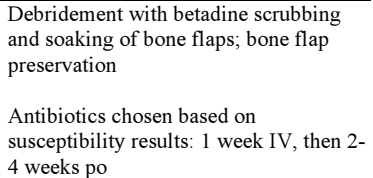 \\
\hline Chu et al. ${ }^{11}$ & $\begin{array}{l}2 \text { cases of brain abscess after } \\
\text { craniotomy for tumor }\end{array}$ & $\begin{array}{l}\text { Surgical drainage } \\
\text { Nafcillin IV x } 6 \text { weeks } \\
\text { Penicillin G IV x } 6 \text { weeks }\end{array}$ \\
\hline $\begin{array}{l}\text { Critchley } \\
\text { and } \\
\text { Strachan }\end{array}$ & $\begin{array}{l}2 \text { cases of subdural empyema after } \\
\text { burr hole evacuation of chronic SDH } \\
\text { (1 co-infection with Lactococcus } \\
\text { species) }\end{array}$ & $\begin{array}{l}\text { Craniotomy (1 delayed), evacuation of } \\
\text { subdural empyemas } \\
\text { Vancomycin/ceftriaxone IV x } 6 \text { weeks, } \\
\text { Penicillin/cefotaxime IV x } 6 \text { weeks }\end{array}$ \\
\hline Jakab et al. $^{5}$ & $\begin{array}{l}3 \text { patients with } P \text {. acnes infections } \\
\text { after craniotomy }\end{array}$ & $\begin{array}{l}\text { Removal of infected bone flap in two } \\
\text { patients and aspiration brain abscess in } \\
\text { one patient } \\
\text { All received intravenous therapy } \\
\text { between 3-8 weeks (exact antibiotics not } \\
\text { specified) }\end{array}$ \\
\hline Jallo et al. $^{6}$ & $\begin{array}{l}3 \text { cases after duraplasty: } 2 \text { epidural } \\
\text { collections, } 1 \text { subdural }\end{array}$ & $\begin{array}{l}\text { Drainage (all 3), flap removal (2) } \\
\text { Levofloxacin IV x 2-4 weeks, then po x } \\
\text { 4-8 weeks }\end{array}$ \\
\hline $\begin{array}{l}\text { Maniatis } \\
\text { and } \\
\text { Vassilouthis } \\
8\end{array}$ & $\begin{array}{l}1 \text { case of infected hematoma after } \\
\text { craniotomy for SAH }\end{array}$ & $\begin{array}{l}\text { Infected extradural hematoma evacuated } \\
\text { Cephacetrile + gentamicin IV x 10d }\end{array}$ \\
\hline $\begin{array}{l}\text { Richards et } \\
\text { al. }{ }^{12}\end{array}$ & $\begin{array}{l}2 \text { cases of intracerebral abscess after } \\
\text { aneurysm clipping }\end{array}$ & $\begin{array}{l}\text { Operative drainage } \\
\text { Ampicillin/gentamicin/metronidazole } \\
\text { IV }\end{array}$ \\
\hline
\end{tabular}


not possible to determine a minimum effective antibiotic duration. We recommend a minimum of three weeks of intravenous antibiotic therapy followed by oral step down therapy for three to six more weeks. Although some authors have advocated preservation of the bone flap in patients with post-craniotomy infections, ${ }^{8,10}$ in our experience removal of the craniotomy flap for $P$. acnes infections is needed because this organism is difficult to eradicate without removal of foreign material and necrotic debris. Before considering cranioplasty for reconstruction of the skull defect, an adequate amount of time must pass in order to ensure that the infection has resolved. In all but one patient (Case 6), we had had uniformly good cranioplasty outcomes with a delay of six months. We are uncertain why this patient had a poor outcome. However, this case illustrates an unusually aggressive presentation of a relatively indolent skin organism with significant patient morbidity.

Most early publications regarding $P$. acnes infections in neurosurgical patients were reports of shunt infections..$^{3,17-20}$ More recently, several articles describing $P$. acnes infections after craniotomy have been published. ${ }^{4-12}$ Table 2 is a summary of 19 previously reported cases of non-shunt related P. acnes infection following neurosurgical interventions for which details regarding management were published. The antibiotic regimens and surgical treatment are shown if they were reported in the original manuscript.

Propionibacterium acnes is a relatively indolent member of the normal skin flora. Human infections are rare, but they are being recognized with increasing frequency following neurosurgical procedures. Based on our experience with postcraniotomy CNS infections caused by $P$. acnes, we recommend surgical debridement including bone flap removal followed by minimum of three weeks of intravenous antibiotic therapy followed by oral step down therapy for an additional three to six weeks.

\section{REFERENCES}

1. Brook I, Frazier EH. Infections caused by Propionibacterium species. Rev Infect Dis. 1991; 13(5): 819-22.

2. Brook I. Meningitis and shunt infection caused by anaerobic bacteria in children. Pediatr Neurol. 2002; 26(2): 99-105.

3. Thompson TP, Albright AL. Propionibacterium [correction of Proprionibacterium] acnes infections of cerebrospinal fluid shunts. Childs Nerv Syst. 1998; 14(8): 378-80.
4. Critchley G, Strachan R. Postoperative subdural empyema caused by Propionibacterium acnes--a report of two cases. $\mathrm{Br} \mathrm{J}$ Neurosurg. 1996; 10(3): 321-3.

5. Jakab E, Zbinden R, Gubler J, Ruef C, von Graevenitz A, Krause M. Severe infections caused by Propionibacterium acnes: an underestimated pathogen in late postoperative infections. Yale $\mathbf{J}$ Biol Med. 1996; 69(6): 477-82.

6. Jallo GI, Koslow M, Hanna BA, Carson LA. Propionibacterium as a cause of postneurosurgical infection in patients with dural allografts: report of three cases. Neurosurgery. 1999; 44(5): 1138-41.

7. Kamme C, Soltesz V, Sundbarg G. Aerobic and anaerobic bacteria in neurosurgical infections. Per-operative culture with flexible contact agar film. J Hosp Infect. 1984; 5(2): 147-54.

8. Maniatis A, Vassilouthis J. Propionibacterium acnes infection complicating craniotomy. J Hosp Infect. 1980; 1(3): 261-4.

9. Barazi SA, Gnanalingham KK, Chopra I, van Dellen JR. Delayed postoperative intracerebral abscess caused by Proprionibacterium acnes: case report and review of the literature. Br J Neurosurg. 2003; 17(4): 336-9.

10. Bruce JN, Bruce SS. Preservation of bone flaps in patients with postcraniotomy infections. J Neurosurg. 2003; 98(6): 1203-7.

11. Chu RM, Tummala RP, Hall WA. Focal intracranial infections due to Propionibacterium acnes: report of three cases. Neurosurgery. 2001; 49(3): 717-20.

12. Richards J, Ingham HR, Hickman J, Crawford PJ, Sengupta RP, Mendelow AD. Focal infections of the central nervous system due to Propionibacterium acnes. J Infect 1989; 18(3): 279-82.

13. Brook I. Infection caused by Propionibacterium in children. Clin Pediatr (Phila). 1994; 33(8): 485-90.

14. Noble WC. Skin microbiology: coming of age. J Med Microbiol. 1984; 17(1): 1-12.

15. van Ek B, Dijkmans BA, van Dulken H, Mouton RP, Hermans J, van Furth R. Effect of cloxacillin prophylaxis on the bacterial flora of craniotomy wounds. Scand J Infect Dis. 1990; 22(3): 345-52.

16. van Ek B, Dijkmans BA, Van Dulken H, Mouton RP, Van Furth R. Efficacy of cloxacillin prophylaxis in craniotomy: a one year follow-up study. Scand J Infect Dis. 1991; 23(5): 617-23.

17. Beeler BA, Crowder JG, Smith JW, White A. Propionibacterium acnes: pathogen in central nervous system shunt infection. Report of three cases including immune complex glomerulonephritis. Am J Med. 1976; 61(6): 935-8.

18. Everett ED, Eickhoff TC, Simon RH. Cerebrospinal fluid shunt infections with anaerobic diphtheroids (Propionibacterium species). J Neurosurg. 1976; 44(5): 580-4.

19. Fokes EC, Jr. Occult infections of ventriculoatrial shunts. J Neurosurg. 1970; 33(5): 517-23.

20. Skinner PR, Taylor AJ, Coakham H. Propionibacteria as a cause of shunt and postneurosurgical infections. J Clin Pathol. 1978; 31(11): 1085-9. 